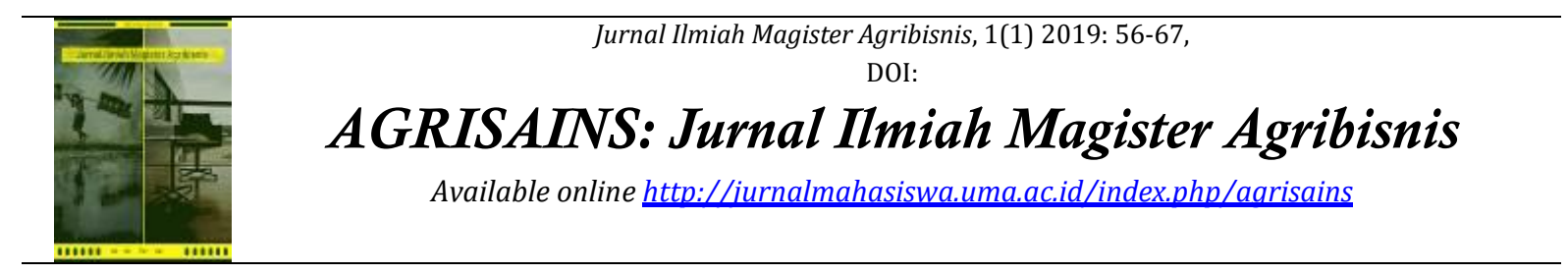

\title{
Hubungan Iklim Terhadap Produksi Serta Pendapatan Petani Karet di Kabupaten Padang Lawas Utara
}

\section{The Relationship of Climate to Production and Income of Rubber Farmers in the District of Padang Lawas Utara}

\author{
Irwansyah Nasution'), Tumpal H.S. Siregar'), Erwin Pane ${ }^{3)}$ \\ 1) Program Studi Magister Agribisnis, Pascasarjana, Universitas Medan Area, Indonesia \\ 2)Magister Agribisnis, Pascasarjana, Universitas Medan Area, Indonesia \\ 3) Fakultas Pertanian, Universitas Medan Area, Indonesia
}

\begin{abstract}
Abstrak
Penelitian ini mengkaji hubungan iklim terhadap produksi serta pendapatan petani karet pada tiga kecamatan di Kabupaten Padang Lawas Utara. Penelitian ini bertujuan untuk mengetahui pengaruh iklim terhadap produksi tanaman karet di Kabupaten Padang Lawas Utara, untuk mengetahui perbedaan pendapatan petani karet pada musim hujan dan musim kemarau. Penelitian ini dilaksanakan pada bulan Maret sampai dengan Mei 2017. Hasil penelitian menunjukkan bahwa faktor iklim terutama curah hujan dan hari hujan sangat berpengaruh terhadap produksi karet di tiga kecamatan di Kabupaten Padang Lawas Utara dimana curah dan hari hujan yang meningkat berakibat pada berkurangnya hari penyadapan dan pada akhirnya mengurangi produksi karet. Kemudian terdapat perbedaan yang sangat nyata/signifikan pendapatan petani pada musim hujan dibandingkan dengan musim kemarau. Pendapatan petani dimusim kemarau lebih tinggi dibandingkan pada musim hujan.

Kata kunci : Iklim, Musim, Produksi Karet, Pendapatan Petani, Padang Lawas Utara
\end{abstract}

\begin{abstract}
This study examines the relationship of Climate Variables with Rubber Yield And Farmer Income In Three Subdistricts of Padang Lawas Utara. This study aims to (1) to determine the effect of climate variable to rubber yield and, (2) To know the difference of farmer's income in rainy season and dry season. This research was conducted in March until May 2017. The result of research is climatic variable especially rainfall and rainy day very significant for influential rubber yields in Three Subdistricts in Padang Lawas Utara. This may indicate that increasing rainfall amounts with higher rainy days cause a decrease in tapping days resulting in reduction of rubber productivity. There results also showed that farmers' income in rainy season difference in dry season whereas farmer income in dry season is higher than rainy season.

Keywords : Climate, Season, Rubber Yield, Farmer Income, Padang Lawas Utara
\end{abstract}

How to Cite: Nasution, I., T.H.S. Siregar \& E. Pane. (2019). Hubungan Iklim Terhadap Produksi Serta Pendapatan Petani Karet di Kabupaten Padang Lawas Utara. Jurnal Ilmiah Magister Agribisnis, 1(1) $2019: 56-67$,

*E-mail: erwinpane@staff.uma.ac.id ISSN 2550-1305 (Online) 


\section{PENDAHULUAN}

Karet (Hevea brasiliensis Muell. Arg) merupakan salah satu komoditas perkebunan yang penting di Indonesia. Komoditas ini sudah dikenal dan dibudidayakan dalam kurun waktu yang relatif lebih lama daripada komoditas perkebunan lainnya. Sayangnya, posisi Indonesia yang pada awal pembudidayaan karet merupakan penghasil karet utama dunia sudah digantikan oleh Malaysia dan Thailand (Siregar, 2013).

Berdasarkan data pada direktorat jendral perkebunan, luas areal tanaman karet di Indonesia pada tahun 2014 adalah seluas 3,64 juta hektar dengan produksi nasional karet sebesar 3,18 juta ton karet kering yang dihasilkan 85\% merupakan perkebunan karet rakyat dan hanya $8 \%$ perkebunan besar milik swasta serta $7 \%$ perkebunan besar milik negara dengan produksi terbanyak berasal dari Sumatera (Direktorat Jenderal Perkebunan, 2015).

Data Kementerian Pertanian menunjukkan hasil produktivitas rata-rata Perkebunan Besar Negara (PBN) adalah $1.036 \mathrm{~kg} / \mathrm{ha} / \mathrm{th}$ - $1.372 \mathrm{~kg} / \mathrm{ha} / \mathrm{th}$ dan Perkebunan Besar Swasta (PBS) sekitar $1.199 \mathrm{~kg} / \mathrm{ha} / \mathrm{th}$ - $1.621 \mathrm{~kg} / \mathrm{ha} / \mathrm{th}$ (Pusat Penelitian Karet, 2010). Bila dibandingkan dengan Malaysia dan Thailand, tingkat produktivitas per hektar lahan di Indonesia masih tergolong rendah. Thailand dengan luas areal perkebunan 2,6 juta hektar memiliki produktivitas $1.699 \mathrm{~kg} / \mathrm{ha}$. Sedangkan Malaysia dengan luas areal perkebunan 1,02 juta hektar memiliki produktivitas 1.411 $\mathrm{kg} /$ ha (Kementerian Koordinator Bidang Perekonomian, 2008).

Salah satu penyebab utama rendahnya produktivitas dan mutu karet di Indonesia disebabkan oleh pengelolaan perkebunan karet yang seadanya dan kurangnya penyerapan teknologi, penggunaan bibit unggul yang tidak baik dan kurang seragam dan pengaruh kondisi lingkungan (Irsal dan Haryati, 2015).

Meskipun demikian, peranan Indonesia sebagai produsen karet alam dunia masih dapat diraih kembali dengan memperbaiki teknik budidaya dan pasca panen/pengolahan, sehingga produktivitas dan kualitasnya dapat ditingkatkan secara optimal. Upaya tersebut dapat dilakukan secara konvensional maupun secara inkonvensional. Secara konvensional dilakukan usaha memperoleh bibit unggul melalui persilangan buatan antara dua tetua yang kemudian diseleksi berdasarkan karakter produksi dan ketahanan penyakit. Secara inkonvensial yaitu menggunakan teknologi tertentu dalam merekayasa suatu sifat tertentu sehingga dihasilkan suatu cara atau produk yang lebih baik dari sebelumnya (Aidi, dkk, 2011).

Beberapa klon telah dihasilkan melalui persilangan buatan dengan potensi produksi karet kering di atas 2 ton/ha/tahun diantaranya adalah klon IRR 112 dan IRR 118 (Woelan, dkk, 2014). Cara lain adalah pemberian stimulan sejak awal penyadapan pada klon IRR 39 dapat meningkatkan produksi sebesar $170 \%$, peningkatan produktivitas proses budidaya karet alam dengan pendekatan green productivity, perbaikan genetic dan penyediaan bibit tanaman karet melalui pendekatan bioteknologi dan beberapa teknik budidaya lainnya (Marimin, dkk, 2014).

Secara nasional, Sumatera Utara memiliki luas tanaman karet terbesar kedua dengan luas 433.121 hektar dengan produksi 418.919 ton dimana luas areal yang paling besar ada di kabupaten Mandailing Natal (55.128 ha), diikuti oleh kabupaten Langkat (35.971 ha), Humbang Hasundutan (25.974 ha) dan Padang Lawas Utara (25.660 ha).

Sejak dekade 1980 hingga tahun 2015, permasalahan karet di Sumatera Utara adalah rendahnya produktivitas dan mutu karet yang dihasilkan, khususnya oleh petani karet rakyat. Sebagai gambaran, produksi karet rakyat hanya $812 \mathrm{~kg} \mathrm{KK} / \mathrm{ha} / \mathrm{thn}$ (Direktorat Jenderal Perkebunan, 2015). 
Walaupun terdapat perbaikan pada teknik budidaya, pasca panen dan pengolahan untuk meningkatkan produksi karet namun terdapat faktor yang belum bisa diatasi secara langsung yaitu iklim. Produksi karet sangat tergantung pada faktor iklim (Satheesh dan Jacob, 2011). Proses pertumbuhan, hasil dan penyakit tanaman karet, juga sangat dipengaruhi oleh iklim (Zomer, dkk, 2014)

Varietas dengan sifat ketahanan yang tinggi terhadap suhu yang meningkat sangat dibutuhkan untuk perluasan penanaman karet. Perbaikan pembiakan dan klonal produksi karet dengan semakin menghangatnya suhu sangatlah penting di masa perubahan iklim (Andrian, dkk, 2014).

Penelitian tentang pengaruh iklim terhadap produksi karet sangat jarang dan terbatas, hanya terdapat beberapa penelitian yang mencari hubungan antara parameter cuaca/iklim dengan produksi karet (Rao, dkk, 1998). Pada penelitian ini akan dipelajari hubungan antara faktor iklim dengan produksi dan pendapatan petani karet di kabupaten Padang Lawas Utara.

\section{METODE PENELITIAN}

Lokasi penelitian yang diteliti adalah kecamatan Batang Onang, Hulu Sihapas dan Padang Bolak Julu. Kegiatan penelitian ini dilaksanakan selama 3 (tiga bulan) terhitung mulai bulan Maret sampai dengan Mei 2017. Lokasi penelitian ditentukan pada kecamatan yang memiliki radius 5 (lima) kilometer dari Stasiun Meteorologi Aek Godang. Pemilihan ini didasarkan pada keadaan geomorfologi Padang Lawas Utara yang tidak datar serta berbukit bukit sehingga pengaruh iklim yang diamati di Stasiun Meteorologi Aek Godang hanya akan signifikan bila jaraknya $<5 \mathrm{~km}$ dari lokasi pengamatan iklim.

Sampel dipilih dengan metode purposive sampling yaitu sampel dipilih berdasarkan pertimbangan tertentu dengan tujuan untuk memperoleh satuan sampling yang memiliki karakteristik atau kriteria yang dikehendaki dalam pengambilan sampel. Dengan metode ini diperoleh 3 kecamatan yang paling dekat dengan Stasiun Meteorologi Aek Godang.

Tiap kecamatan dipilih masing masing 2 desa yaitu desa Aek Godang dan Aek Nauli di kecamatan Hulu Sihapas. Desa Ubar dan Padang Baluas di kecamatan Padangbolak Julu. Kemudian desa Padang Bujur Baru dan Janji Manahan di Kecamatan Batang Onang. Jumlah sampel adalah $10 \%$ dari populasi desa sehingga diperoleh sebanyak 49 orang petani yang akan dijadikan sampel penelitian (tabel 1). Teknik penentuan jumlah sampel petani dilakukan dengan teknik judgment sampling yaitu teknik pengambilan sampling dimana sampel yang dipilih berdasarkan penilaian peneliti bahwa dia atau seseorang yang paling baik jika dijadikan sampel penelitiannya sehingga pada penelitian ini petani sampel adalah petani yang memiliki kebun karet paling dekat dengan Stasiun Meteorologi Aek Godang.

Tabel 1. Jumlah sampel penelitian

\begin{tabular}{llrr}
\hline Kecamatan & Desa & Jumlah & Jumlah Sampel \\
& & Populasi & \\
\hline Padang Bolak Julu & Padang Bujur Baru & 112 & 12 \\
& Janji Manahan & 80 & 8 \\
Batang Onang & Aek Godang & 130 & 13 \\
Hulu Sihapas & Aek Nauli & 50 & 5 \\
& Ubar & 70 & 7 \\
\hline
\end{tabular}

Sumber : Data Sekunder (diolah), 2017 
Teknik pengumpulan data yang dilakukan adalah menghimpun data primer melalui angket atau kuisioner dalam bentuk gabungan kuisioner dan data sekunder dari data statistik iklim dari Stasiun Meteorologi Aek Godang. Data primer berupa informasi tentang sistem usaha tani karet, produksi, harga, tempat pemasaran dan pendapatan. Data primer diperoleh melalui wawancara dengan responden yang telah ditentukan dengan menggunakan daftar pertanyaan terstruktur yang telah dipersiapkan sebelumnya dan wawancara tidak terstruktur dimana wawancara langsung dilakukan secara spontan, bebas berdasarkan pengembangan proses tanya jawab di lapangan. Data sekunder berupa data iklim antara lain; curah hujan, hari hujan, suhu, kelembaban, penyinaran matahari diperoleh dari Stasiun Meteorologi Aek Godang. Periode time series data iklim yang dikumpulkan adalah data 3 tahun yaitu tahun 2014 sampai dengan 2016 . Perolehan data sekunder juga bersumber dari berbagai literature, studi kepustakaan maupun studi dokumentasi.

Data dianalisis dengan menggunakan program Microsoft Office Excel 2010 dilakukan analisis sebagai berikut ;

a. Regresi Linier Berganda, untuk mengestimasi berbagai hubungan atau variabel yang mempengaruhi produksi karet. Persamaan pada regresi linier berganda adalah sebagai berikut :

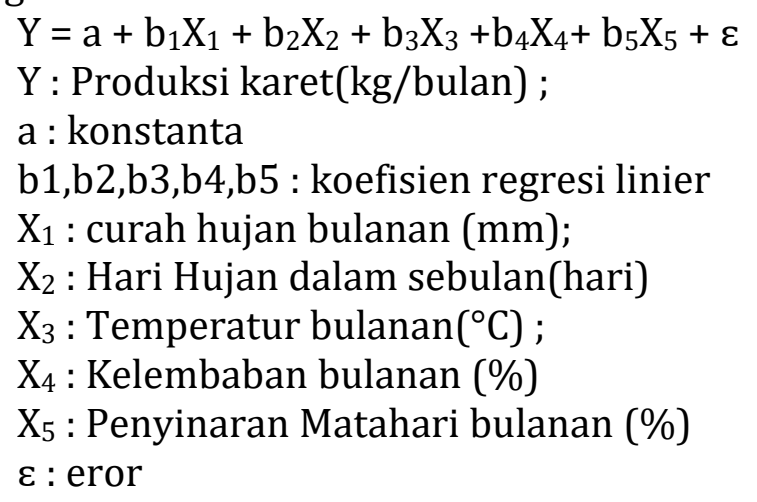

b. uji t untuk mengetahui apakah terdapat perbedaan pendapatan petani antar musim baik didalam tiap kecamatan dngan rumus sebagai berikut :

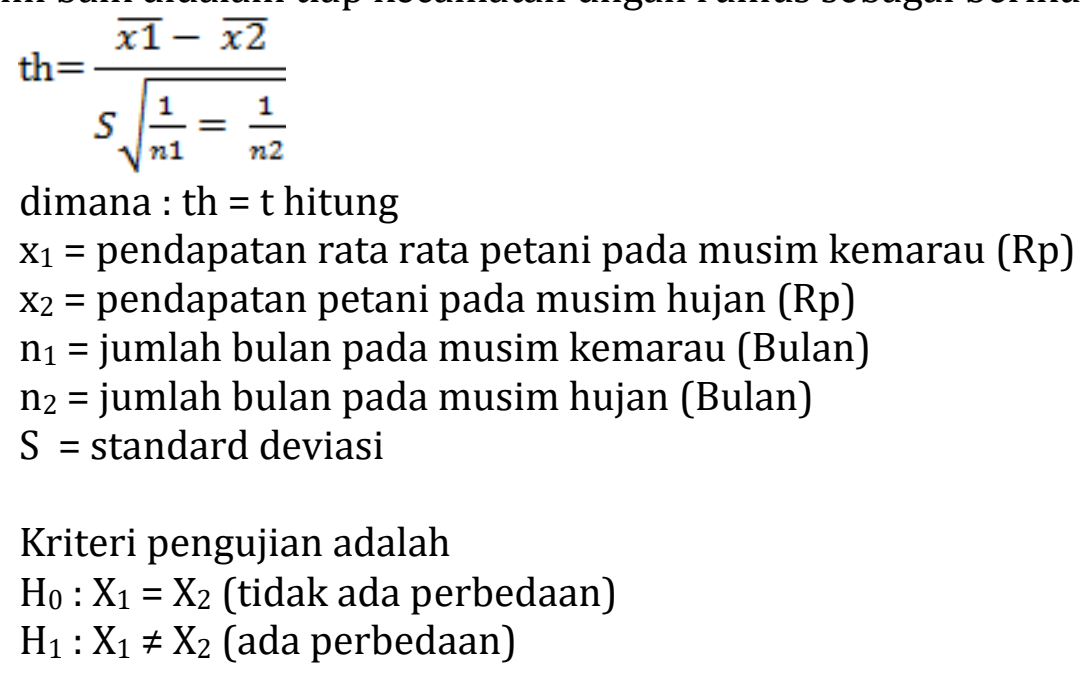

\section{HASIL DAN PEMBAHASAN}

Petani responden di daerah penelitian memiliki rata rata umur 50 tahun dengan rentang usia antara 40 hingga 60 tahun. Menurut Hurlock (2004) berdasarkan kelompok usia dewasa, responden dapat dikelompokkan menjadi tiga yaitu usia dewasa awal atau 
Nasution, I., T.H.S. Siregar \& E. Pane. Hubungan Iklim Terhadap Produksi Serta Pendapatan Petani Karet di Kabupaten Padang Lawas Utara.

dini ( usia 18-40 tahun) sebesar 14,06 \%, usia dewasa madya (40-60 tahun) 54,69 \% dan usia dewasa lanjut (usia diatas 60 tahun) 31,25 \%. Jika dilihat dari usia petani responden, dapat disimpulkan bahwa petani di tiga kecamatan sebagian besar merupakan petani yang tidak lagi berusia muda. Petani yang tidak lagi muda akan mengalami penurunan pada fisik dan stamina dan hal ini akan berimplikasi pada produksi karet yang dihasilkan.

Secara umum, petani responden rata rata menamatkan SMA $25 \%$ sedangkan sisanya memiliki pendidikan SMP (60\%) dan SD (15\%). Tingkat pendidikan petani responden akan berpengaruh pada tingkat penyerapan inovasi baru dalam teknologi dan ilmu pengetahuan. Semakin tinggi pendidikan petani maka akan semakin besar pula peluangnya untuk menerapkan inovasi teknologi dalam usaha untuk meningkatkan produksi hasil usaha karet.

Luas lahan kebun karet rata rata yang dimiliki petani responden adalah 0-1 hektar (15\%), 1-2 hektar (65\%), 2-4 hektar (15\%), > 4 hektar (5\%). Luas lahan berkorelasi positif dengan kuantitas produksi yang dihasilkan oleh petani tiap harinya. Semakin besar luas lahan yang dimiliki petani maka petani tersebut akan semakin banyak memproduksi lateks tiap harinya.

Jumlah pohon karet yang dimiliki petani adalah sebanyak 250 pohon/ha (15\%), 250-500 pohon/ha (25\%), 500-750 pohon/ha (60\%). Kerapatan tanaman yang rendah merupakan salah satu penyebab rendahnya produktivitas. Untuk mencapai produktivitas tinggi perlu dipertahankan kerapatan optimal dan meningkatkan produksi per pohon. Kenyataan di lapangan menunjukkan bahwa penurunan kerapatan merupakan masalah yang sering dihadapi para petani sejak bibit karet ditanam di lapangan sampai berumur lanjut.

Rendahnya kerapatan tanaman disebabkan oleh beberapa faktor, yaitu: 1) teknik penanaman yang tidak tepat, baik dari segi waktu maupun cara tanam, yang dapat berakibat pada kematian tanaman, serta penyulaman tanaman yang kurang intensif dan cenderung terlambat, dan 2) kerusakan tanaman oleh angin dan penyakit akar putih (Rigidoporus microporus) (Siagian, 1995).

Umur pohon rata rata yang dimiliki petani adalah 0- 10 tahun (10\%), 10-15 tahun (15\%), 15-20 tahun (65 \%) dan > 20 tahun (10\%) seperti pada

Umur pohon juga berkorelasi pada kuantitas produksi dimana semakin tua pohon semakin berkurang produksinya. Berdasarkan hasil wawancara beberapa petani yang memiliki kebun karet diatas 20 tahun belum melakukan peremajaan dikarenakan kebun karet tersebut masih menghasilkan. Petani masih bisa melakukan penyadapan pada batang karet dan hasil cukup tinggi. Hal ini dikarenakan kulit karet pada batang masih bisa disadap dan menghasilkan getah atau dengan dengan kata lain belum mengalami mati kulit. Namun, Setiawan dan Andoko (2005) menyatakan bahwa beberapa kebun di Sumatera Utara sudah tidak produktif lagi pada umur 15-18 tahun karena sudah kehabisan cadangan kulit akibat penyadapan berat, melebihi norma sadap yang telah ditentukan.

\section{Analisis Pengaruh Faktor Iklim terhadap Produksi}

Hasil produksi getah karet didapatkan dari hasil produksi getah karet dalam kurun waktu penyadapan dua minggu oleh petani. Hasil penyadapan dua minggu kemudian diakumulasikan menjadi produksi getah karet dalam satu bulan dan selanjutnya menjadi produksi karet dalam waktu satu tahun. Hasil produksi ini kemudian dianalisis untuk mengetahui pengaruh faktor faktor iklim dengan hasil sebagai berikut ; 
Tabel 2. Hasil korelasi faktor faktor iklim terhadap produksi di Kecamatan Padang Bolak Julu

\begin{tabular}{|c|c|c|c|c|c|}
\hline & $\begin{array}{l}\text { Curah Hujan } \\
\text { (mm) }\end{array}$ & $\begin{array}{c}\text { Hari Hujan } \\
\text { (hari) }\end{array}$ & Suhu $\left({ }^{\circ} \mathrm{C}\right)$ & $\begin{array}{c}\text { Kelembaban } \\
(\%)\end{array}$ & $\begin{array}{c}\text { Penyinaran } \\
\text { Matahari (\%) }\end{array}$ \\
\hline Produksi (kg) & $-0,86$ & $-0,83$ & 0,31 & 0,34 & 0,63 \\
\hline
\end{tabular}

Sumber : Data Primer (diolah), 2017

Untuk melihat hubungan masing masing faktor iklim terhadap produksi dilakukan analysis korelasi. Hasil korelasi faktor faktor iklim di kecamatan Padang Bolak Julu disajikan pada Tabel 2. Dari analisis korelasi tabel 2 diketahui bahwa faktor curah hujan, hari hujan mempunyai korelasi yang paling tinggi terhadap produksi karet di Padang Bolak Julu yakni sebesar $(-0,87$ dan $-0,83)$ kemudian diikuti oleh penyinaran matahari $(-$ $0,64)$, kelembaban $(0,34)$ dan suhu $(0,31)$. Artinya setiap pertambahan $1 \mathrm{~mm}$ hujan dapat menyebabkan penurunan produksi sebesar $0,87 \mathrm{~kg}$ atau setiap pertambahan 1 hari hujan akan menyebabkan penuruan produksi sebesar 0,83 kg. Faktor suhu, kelembaban dan penyinaran matahari berkorelasi sebesar masing masing 0,31;0,34 dan $-0,63$ terhadap produksi.

Selanjutnya untuk mengetahui pengaruh faktor iklim (secara bersama sama) terhadap produksi dilakukan analysis regresi linier berganda. Hasil analysis menunjukkan $\mathrm{R}^{2}=0,88$ artinya faktor iklim menyumbang pengaruh sebesar 88 persen terhadap produksi karet di Kecamatan Padang Bolak Julu dengan persamaan regresi ;

$\mathrm{Y}=184,05+\left(-0,03 \mathrm{X}_{1}\right)+\left(-0,40 \mathrm{X}_{2}\right)+\left(-3,21 \mathrm{X}_{3}\right)+0,06 \mathrm{X}_{4}+\left(-0,40 \mathrm{X}_{5}\right)$

dimana $\mathrm{X}_{1}$ adalah curah hujan,

$\mathrm{X}_{2}$ : hari hujan,

$\mathrm{X}_{3}$ : suhu

$\mathrm{X}_{4}$ : kelembaban

$\mathrm{X}_{5}$ : penyinaran matahari.

Tabel 3. Hasil korelasi faktor iklim terhadap produksi di Kecamatan Batang Onang

\begin{tabular}{|c|c|c|c|c|c|}
\hline & $\begin{array}{l}\text { Curah Hujan } \\
(\mathrm{mm})\end{array}$ & $\begin{array}{c}\text { Hari Hujan } \\
\text { (hari) }\end{array}$ & Suhu $\left({ }^{\circ} \mathrm{C}\right)$ & $\begin{array}{c}\text { Kelembaban } \\
(\%)\end{array}$ & $\begin{array}{c}\text { Penyinaran } \\
\text { Matahari (\%) }\end{array}$ \\
\hline Produksi (kg) & $-0,84$ & $-0,80$ & 0,28 & 0,41 & $-0,57$ \\
\hline
\end{tabular}

Sumber : Data Primer (diolah),2017

Dari tabel 3 analisis korelasi ini disimpulkan bahwa faktor curah hujan dan hari hujan mempunyai korelasi relatif yang tinggi terhadap produksi karet di Padang Bolak Julu yakni sebesar $(-0,84$ dan $-0,80)$. Artinya setiap pertambahan $1 \mathrm{~mm}$ hujan dapat menyebabkan penurunan produksi sebesar 0,84 $\mathrm{kg}$ atau setiap pertambahan 1 hari hujan akan menyebabkan penuruan produksi sebesar 0,80 kg. Faktor suhu, kelembaban dan penyinaran matahari berkorelasi sebesar masing masing 0,28; 0.41 dan -0,57 terhadap produksi.

Selanjutnya untuk mengetahui pengaruh faktor iklim (secara bersama sama) terhadap produksi dilakukan analysis regresi linier berganda. Hasil analisis menunjukkan $\mathrm{R}^{2}=0,84$ artinya faktor iklim menyumbang pengaruh sebesar 84 persen terhadap produksi karet di Kecamatan Batang Onang dengan persamaan regresi

$Y=152,99+\left(-0,02 X_{1}\right)+\left(-0,25 X_{2}\right)+\left(-3,02 X_{3}\right)+0,09 X_{4}+\left(-0,19 X_{5}\right)$

dimana $\mathrm{X}_{1}$ adalah curah hujan,

$\mathrm{X}_{2}$ : hari hujan,

$\mathrm{X}_{3}$ : suhu dan

$\mathrm{X}_{4}$ : kelembaban 
Nasution, I., T.H.S. Siregar \& E. Pane. Hubungan Iklim Terhadap Produksi Serta Pendapatan Petani Karet di Kabupaten Padang Lawas Utara.

$\mathrm{X}_{5}$ : penyinaran matahari

Tabel 4. Hasil korelasi faktor iklim terhadap produksi di Kecamatan Hulu Sihapas

\begin{tabular}{cccccc}
\hline & $\begin{array}{c}\text { Curah Hujan } \\
(\mathrm{mm})\end{array}$ & $\begin{array}{c}\text { Hari Hujan } \\
\text { (hari) }\end{array}$ & Suhu $\left({ }^{\circ} \mathrm{C}\right)$ & $\begin{array}{c}\text { Kelembaban } \\
(\%)\end{array}$ & $\begin{array}{c}\text { Penyinaran } \\
\text { Matahari (\%) }\end{array}$ \\
\cline { 2 - 6 } Produksi $(\mathrm{kg})$ & $-0,84$ & $-0,80$ & 0,28 & 0,41 & $-0,60$ \\
\hline
\end{tabular}

Sumber : Data Primer (diolah), 2017

Dari analisis korelasi faktor iklim terhadap produksi di Kecamatan Hulu SIhapas pada tabel 4, dapat diketahui bahwa faktor curah hujan dan hari hujan mempunyai korelasi yang tinggi terhadap produksi karet di Padang Bolak Julu yakni sebesar $(-0,81$ dan -0,79). Artinya setiap pertambahan $1 \mathrm{~mm}$ hujan dapat menyebabkan penurunan produksi sebesar 0,81 $\mathrm{kg}$ atau setiap pertambahan 1 hari hujan akan menyebabkan penuruan produksi sebesar $0,79 \mathrm{~kg}$. Faktor suhu, kelembaban dan penyinaran matahari berkorelasi sebesar masing masing 0,38; 0,60 dan -0,60 terhadap produksi.

Selanjutnya untuk mengetahui pengaruh faktor iklim (secara bersama sama) terhadap produksi dilakukan analysis regresi linier berganda. Hasil analysis menunjukkan $\mathrm{R}^{2}=0,88$ artinya faktor iklim menyumbang pengaruh sebesar $88 \%$ terhadap produksi karet di Kecamatan Hulu Sihapas dengan persamaan regresi

$\mathrm{Y}=152,99+\left(-0,02 \mathrm{X}_{1}\right)+\left(-0,25 \mathrm{X}_{2}\right)+\left(-3,02 \mathrm{X}_{3}\right)+0,19 \mathrm{X}_{4}+\left(-0,18 \mathrm{X}_{5}\right)$

dimana $X_{1}$ adalah curah hujan,

$\mathrm{X}_{2}$; hari hujan,

$\mathrm{X}_{3}$; suhu dan

$\mathrm{X}_{4}$; kelembaban.

$\mathrm{X}_{5}$ : penyinaran matahari

\section{Pembahasan Pengaruh Iklim Terhadap Produksi}

Hasil analisis regresi dan korelasi pengaruh faktor iklim pada 3 (tiga) kecamatan di Padang Lawas Utara menunjukkan bahwa faktor iklim sangat mempengaruhi produksi karet terutama curah hujan dan hari hujan. Berdasarkan hasil wawancara, petani mengatakan bahwa bila terjadi hujan apalagi pada pagi hari maka petani tidak melakukan penyadapan karet. Hal ini sesuai dengan penelitian Makkaew (2015) bahwa terjadinya curah hujan yang tinggi berakibat berkurangnya hari penyadapan dan pada akhirnya mengurangi produksi karet.

Pengaruh hari hujan juga sangat signifikan terhadap produksi karet. Sepanjang tahun 2014 s.d 2016 hari hujan rata rata di Stasiun Meteorologi Aek Godang adalah 16 hari setiap bulan dengan jumlah hari terbesar ada pada musim hujan yang bisa terjadi sampai dengan 27 hari hujan (November 2014). Hal ini juga mempengaruhi produksi karena berkurangnya hari penyadapan dan peningkatan intensitas serangan penyakit gugur daun akibat curah hujan yang tinggi.

Wijaya (2013) mengatakan bahwa hujan yang jatuh ke pohon akan menjadi aliran batang. Aliran batang mengalir melalui batang dan cabang pohon dan masuk ke mangkok penyadapan. Hal ini bisa mengakibatkan terbuangnya lateks yang ada di dalam mangkok. Dengan semakin seringnya terjadi hujan maka proses ini juga akan mengurangi produksi lateks.

Penurunan produktivitas juga sering ditemui pada suatu lokasi pertanaman akibat serangan penyakit gugur daun atau gangguan angin. Intensitas serangan penyakit daun erat hubungannya dengan agroklimat setempat. Eksplosi penyakit gugur daun terjadi akibat curah hujan yang tinggi dan merata sepanjang tahun. Pola curah hujan yang demikian dari tahun ke tahun akan dapat memacu perkembangan penyakit gugur daun, 
dan memungkinkan serangan penyakit yang berulang, seperti yang terjadi di Bengkulu dan Kalimantan Barat (Soepadmo, 1990). Penurunan produksi karet akibat curah hujan di Aek Pamingke yang tinggi berkisar antara 20-30 persen (Woelan, dkk, 2014). Curah hujan secara umum memiliki korelasi dengan hari hujan. Beberapa pengaruh dari hari hujan yang sering adalah terganggunya proses penyadapan dan pengumpulan hasil, mencairkan cup lump dan meningkatkan potensi serangan penyakit pada tanaman.

Hilangnya hari sadap dan keterlambatan waktu penyadapan karena hujan dapat diatasi dengan teknologi rain guard. Di India pada tahun normal, 25 hingga 40 hari sadap dapat diselamatkan dengan penggunaan rain guard (Vijayakumar, dkk, 2000). Teknologi rain guard ini telah diterapkan di Kebun Percobaan Balai Penelitian Sembawa. Rainguard tersebut berfungsi untuk membelokkan aliran air hujan yang mengalir melalui batang sehingga tidak masuk ke mangkuk sadap dan menjaga bidang sadap tetap dalam keadaan kering. Dengan mangkok tersebut, air hujan yang jatuh ke dalam mangkok sadap jauh berkurang.

Pengukuran volume air yang masuk ke mangkuk sadap menunjukkan bahwa dengan aplikasi rain guard, air yang masuk mangkuk sadap hanya $20 \%$ sehingga tercucinya lateks oleh air hujan yang masuk ke mangkuk sadap menjadi lebih kecil (Wijaya, 2013).

\section{Analisis Perbedaan Pendapatan Pada Musim Hujan dan Kemarau}

Pendapatan berupa penerimaan petani diperoleh dari hasil penjualan getah karet. Hasil produksi getah karet setiap musimnya berbeda sehingga pendapatan petani juga berbeda. Berdasarkan kriteria disebut musim hujan bila jumlah curah hujan kumulatif selama satu bulan sebesar $150 \mathrm{~mm}$ atau lebih sedangkan bila curah hujannya lebih kecil dari 150 mm/bulan disebut musim kemarau (Irsal dan Haryati, 2015).

Dari pola hujan di Stasiun Meteorologi Aek Godang tahun 2014-2016 disimpulkan bahwa musim hujan 2014 terjadi pada bulan Januari, Maret, April, Mei, Agustus, Oktober, November dan Desember sedangkan sisa bulan lainnya merupakan musim kemarau. Pada tahun 2015 musim hujan terjadi pada bulan Januari, Maret, April, Agustus, Oktober, November dan Desember. Pada tahun 2016 musim hujan terjadi pada bulan Februari, April, Mei dan November. Jumlah musim hujan selama tahun 2014 -2016 adalah 18 bulan sedangkan musim kemarau terjadi selama 18 bulan. Selanjutnya data pendapatan petani itu selama musim hujan dan musim kemarau dianalysis dengan uji $\mathrm{T}$.

Tabel 5. Uji Beda Rata Rata Pendapatan Petani di Kecamatan Padang Bolak Julu Pada Musim Hujan dan Kemarau

\begin{tabular}{lcc}
\hline \multicolumn{1}{c}{ Komponen } & Pendapatan Musim Kemarau & Pendapatan Musim Hujan \\
\hline Rata rata Pendapatan (Rp) & $299.278,-$ & $223.889,-$ \\
Jumlah Observasi & 18 & 18 \\
df & 34 & \\
T Hitung & 2,91 & \\
T Tabel & & \\
(pengujian dua arah) & 2,03 &
\end{tabular}

Sumber :Data Primer (diolah), 2017

Hasil uji beda rata rata pendapatan petani karet pada musim kemarau dan musim hujan di Kecamatan Padang Bolak Julu disajikan pada tabel 5. Hasil analisis uji t di Kecamatan Padang Bolak Julu menunjukkan bahwa t hitung $(2,91)$ lebih besar dari $t$ tabel $(2,03)$, artinya ada perbedaan nyata antara pendapatan petani karet pada musim kemarau dan musim hujan. Rata pendapatan petani pada musim kemarau adalah Rp. 299.278,- sedangkan pada musim penghujan Rp. 223.889,- perbulan/ha. 
Nasution, I., T.H.S. Siregar \& E. Pane. Hubungan Iklim Terhadap Produksi Serta Pendapatan Petani Karet di Kabupaten Padang Lawas Utara.

Tabel 6. Uji Beda Rata Rata Pendapatan Petani di Kecamatan Batang Onang Pada Musim Hujan dan Kemarau

\begin{tabular}{lcc}
\hline \multicolumn{1}{c}{ Komponen } & Pendapatan Musim Kemarau & Pendapatan Musim Hujan \\
\hline Rata rata Pendapatan (Rp) & $269.889,-$ & $208.778,-$ \\
Jumlah Observasi & 18 & 18 \\
Df & 34 & \\
T Hitung & 2,68 & \\
T Tabel (pengujian dua arah) & 2,03 & \\
\hline
\end{tabular}

Sumber :Data Primer (diolah), 2017

Hasil uji beda rata rata pendapatan petani karet pada musim kemarau dan musim hujan disajikan pada tabel 6. Hasil analisis uji t di Kecamatan Batang Onang menunjukkan bahwa t hitung $(2,68)$ lebih besar dari t tabel $(2,03)$, yang berarti ada perbedaan nyata antara pendapatan petani karet pada musim kemarau dan musim hujan. Rata rata pendapatan petani di kecamatan Batang Onang pada musim kemarau adalah sebesar Rp. 269.889,- perbulan/ha sedangkan pada musim hujan adalah Rp. 208.778,- perbulan/ha.

Tabel 7. Uji Beda Rata Rata Pendapatan Petani di Kecamatan Hulu Sihapas Pada Musim Hujan dan Kemarau

\begin{tabular}{lcc}
\hline \multicolumn{1}{c}{ Komponen } & Pendapatan Musim Kemarau & Pendapatan Musim Hujan \\
\hline Rata rata Pendapatan (Rp) & $288.811,-$ & $223.898,-$ \\
Jumlah Observasi & 18 & 18 \\
df & 34 & \\
T Hitung & 2,59 & \\
T Tabel (pengujian dua arah) & 2,03 & \\
\hline
\end{tabular}

Sumber :Data Primer (diolah), 2017

Hasil uji perbedaan rata rata pendapatan petani karet pada musim kemarau dan musim hujan di kecamatan Hulu Sihapas disajikan pada tabel 7. Hasil analisis uji t di Kecamatan Hulu Sihapas menunjukkan bahwa t hitung $(2,59)$ lebih besar dari t tabel $(2,03)$, yang berarti ada perbedaan nyata antara pendapatan petani karet pada musim kemarau dan musim hujan. Rata rata pendapatan petani di kecamatan Hulu Sihapas pada musim kemarau adalah Rp. 288.811,- perbulan/ha sedangkan pada musim hujan adalah Rp. 223.898,- perbulan/ha.

Secara umum dapat dikatakan bahwa kualitas bahan olahan karet rakyat (bokar) yang dihasilkan oleh petani masih tergolong rendah. Sebagian besar petani menghasilkan bokar dalam bentuk slab. Rata-rata ketebalan slab yang dihasilkan petani lebih dari $10 \mathrm{~cm}$ dengan berat slab berkisar 28 - $80 \mathrm{~kg}$ per keping. Para petani lebih menyukai slab tebal karena alasan menghindari pencurian slab, sedangkan bagi pedagang/tengkulak, dengan membeli slab tebal risiko penyusutan kadar air lebih besar, sehingga pedagang cenderung menekan harga bokar karena alasan tingginya kadar air.

Dilihat dari cara pengolahan bokar, sebagian besar petani banyak menggunakan bahan pembeku yang tidak direkomendasikan yaitu asam sulfat atau yang lebih dikenal masyarakat dengan sebutan cuka para. Cuka para merupakan bahan pembeku yang paling mudah didapat di pasaran. Penggunaan bahan pembeku yang tidak direkomendasikan seperti tawas, pupuk TSP, dan gadung pada bokar, dapat menyebabkan mutu karet menjadi rendah dikarenakan nilai plastisitas karet, baik 
plastisitas awal (Po) maupun plastisitas retensi indeks (PRI) akan turun di bawah standar SIR 20 (Purbaya, dkk, 2011).

Kegiatan penyimpanan bokar yang dilakukan petani menunjukkan bahwa sebagian besar petani masih melakukan hal hal yang dapat menurunkan mutu bokar yaitu dengan merendam dalam air, mengotori bokar dengan tatal, menyimpan dalam kondisi ruang yang lembab dan kotor. Proses perendaman bokar di dalam air yang kotor merupakan hal yang berpotensi menimbulkan kerusakan berupa menurunnya mutu bokar akibat aktivitas mikroorganisme dan menurunnya kadar karet kering (KKK) seiring dengan meningkatnya kadar air yang berpengaruh terhadap harga beli bokar.

Rendahnya mutu bokar yang dihasilkan pada dasarnya bukan tidak disadari oleh petani. Satu hal yang menarik adalah alasan petani untuk menggunakan tatal dan benda asing lainnya ke dalam bongkahan bokar adalah sebagai upaya menambah berat bokar yang dihasilkan. Dari hasil kajian disimpulkan bahwa penerapan Peraturan Menteri Pertanian No. 38/Permentan/OT.140/8/2008 dan Peraturan Menteri Perdagangan No. 53/MDAG/PER/10/2009 mengenai upaya-upaya dalam meningkatkan mutu bokar belum dilaksanakan sepenuhnya di tingkat petani, dikarenakan sosialisasi mengenai peraturan tersebut belum sepenuhnya dilaksanakan ke tingkat petani.

Sesuai dengan mutu bokar yang dihasilkan oleh petani, harga beli yang diberikan oleh pedagang atas bokar atau slab yang dihasilkan menjadi rendah. Hasil analisis data menunjukkan rata rata harga slab berkisar Rp. 4000,-/kg sampai Rp. 6000,-/kg. Anwar (2006) mengatakan bahwa karet sintetik sebagai produk hasil industri memiliki harga yang relatif lebih stabil dibandingkan dengan karet alam.

Selain itu, karet sintetik yang umumnya diproduksi dan dikonsumsi negara industri, harganya cenderung naik sejalan dengan harga bahan baku, kenaikan biaya produksi dan tingkat inflasi dari negara produsen. Hal ini sangat berbeda dengan harga karet alam yang berfluktuasi yang dipengaruhi oleh kondisi alam (cuaca/iklim), nilai tukar dan perkembangan ekonomi negara konsumen.

Penerimaan usahatani diketahui dengan mengalikan harga karet berdasarkan kualitas dikalikan dengan jumlah produksinya. Rata rata penerimaan petani karet di 3 (tiga) kecamatan pada musim kemarau berkisar Rp. 269.889,- sampai dengan Rp. 299.278,- dan pada musim hujan Rp. 208.778,- sampai dengan Rp. 223.898,-.

\section{SIMPULAN}

Hasil analisis regresi menunjukkan bahwa faktor iklim sangat signifikan mempengaruhi produksi karet pada tiga kecamatan di Padang Lawas Utara. Faktor iklim yang berpengaruh negatif adalah curah hujan, hari hujan dan penyinaran matahari. Suhu dan kelembaban udara berpengaruh secara positif. Hasil uji t untuk pendapatan petani di tiga kecamatan menunjukkan ada perbedaan yang nyata antara musim kemarau dengan musim hujan. Pendapatan pada pendapatan musim kemarau lebih tinggi daripada musim hujan.

Hasil penelitian ini perlu disosialisasikan kepada pengambil kebijakan dan petani karet di Padang Lawas Utara. Perlu sosialisasi penggunaan rain guard untuk mengatasi berkurangnya hari dan waktu penyadapan serta transportasi yang diakibatkan oleh intensitas dan hari hujan yang tinggi di Padang Lawas Utara. 
Nasution, I., T.H.S. Siregar \& E. Pane. Hubungan Iklim Terhadap Produksi Serta Pendapatan Petani Karet di Kabupaten Padang Lawas Utara.

\section{DAFTAR PUSTAKA}

Aidi, Zaida Fairuzah, \& Cici Indriani Dalimunthe. (2011). "Uji Resistensi Genotipe Terpilih Dari Plasma Nutfah IRRDB terhadap Penyakit Gugur Daun Corynespora Dengan Metode Cakram Daun. Jurnal Penelitian Karet 29, no. 1 (2011): 16-24.

Anwar, C., (2006). Perkembangan pasar dan prospek agribisnis karet di Indonesia. Lokakarya Budidaya Tanaman Karet, pada tanggal, pp.4-6.

Arifin, Bustanul. (2005). Supply Chain Of Natural Rubber in Indonesia. Associate Profesor Of Agricultural Economics at the University of Lampung.

Andrian, A., Supriadi, S. \& Marpaung, P. (2014). Pengaruh Ketinggian Tempat dan Kemiringan Lereng Terhadap Produksi Karet (Hevea brasiliensis Muell. Arg.) di Kebun Hapesong PTPN III Tapanuli Selatan. Agroekoteknologi, 2(3).

Chandrasekhar, T. et. al.. (2002). Yield performance of trees grown from polycross seeds of rubber (Hevea brasiliensis) in a dry sub humid climate in India. Indian Journal of Natural Rubber Research15(1): 1927.

Direktorat Jenderal Perkebunan. (2015). Statistik Perkebunan Indonesia.

Hurlock, S., Unisys Corporation. (2004). Code type control of caching parameters. U.S. Patent 6,801,883.

Irsal, I. \& Haryati, H., (2015). Pengaruh Curah Hujan dan Hari Hujan Terhadap Produksi Tanaman Karet (Hevea brasiliensis Muell-Arg.) Umur 6, 10 dan 14 Tahun pada PT. Bridgestone Sumatera Rubber Estate Dolok Merangir. Agroekoteknologi, 3(2).

Kementerian Perdagangan Republik Indonesia. (2009). Peraturan Menteri Perdagangan No. 53/2009. Pengawasan Mutu Bahan Olah Komoditi Ekspor Standard Indonesian Rubber yang Diperdagangkan. Kementerian Perdagangan Republik Indonesia, Jakarta.

Kementerian Pertanian Republik Indonesia. (2008). Peraturan Menteri Pertanian 38/2008. Pedoman Pengolahan dan Pemasaran Bahan Olah Karet (Bokar). Kementerian Pertanian Republik Indonesia, Jakarta.

Lestari, D. (2008). Analisis Faktor-faktor yang Mempengaruhi Pendapatan Petani Karet di Kelurahan Air Tiris Kecamatan Kampar. Skripsi Jurusan Sosial Ekonomi Pertanian (Agrobisnis) Fakultas Pertanian Universitas Riau, Pekanbaru.

Marimin, M., et al. (2014). Peningkatan Produktivitas Proses Budidaya Karet Alam dengan Pendekatan Green Productivity: Studi kasus di pt. xyz (The Increase of Natural Rubber Plantations Productivity with Green Productivity Approach: a Case Study at PT. XYZ). Jurnal Agritech33(04): 433-441.

Makkaew, K.R.K. \& Sdoodee, S. (2015). The impact of rainfall fluctuation on days and rubber productivity in Songkhla Province. Journal of Agricultural Technology, 11(1), pp.181-191.

Nazaruddin dan Paimin. (1992). Budidaya dan Pengolahan Karet. Penebar Swadaya, Jakarta.

Omokhafe, K. (2004). Interaction between flowering pattern and latex yield in Hevea brasiliensis Muell. Arg. Crop Breeding and Applied Biotchnology4: 280-284.

Pusat Penelitian Karet.. (2010). Rekomendasi klon karet periode 2006-2010.

Rao, P. S., et. al. (1998). Studies on the relationship between yield and meteorological parameters of para rubber tree (Hevea brasiliensis). Agricultural and Forest Meteorology90(3): 235-245.

Ritonga, I. A., (2015). Teknik Penyadapan Tradisional Pada Tanaman Karet Di Tapanuli Selatan. Jurnal Nasional Ecopedon3(1): 17-20.

Sannia, B., Ismono, R.H. \& Viantimala, B. (2013). Hubungan kualitas karet rakyat dengan tambahan pendapatan petani di Desa program dan non-program. Jurnal Ilmu-Ilmu Agribisnis, 1(1).

Satheesh, P. \& J. Jacob. (2011). Impact of climate warming on natural rubber productivity in different agroclimatic regions of India. Natural Rubber Research24(1): 1-9.

Sembawa, P.P.K.B.P., (2009). Rekomendasi klon karet periode 2006-2010. Pusat Penelitian Karet Balai Penelitian Sembawa, Sembawa.

Setiawan, D. H. and A. Andoko. (2005). Petunjuk Lengkap Budi Daya Karet. Penerbit Agromedia Pustaka.

Siagian, N. (1995). Upaya mempertahankan kerapatan tanaman karet. Warta Pusat Penelitian Karet, 14(1), pp.53-61.

Siregar .H, Sitorus \& S, Sutandi. A. (2012). Potential Analysis of Rubber Smallholding Development in Mandailing Natal Regency, North Sumatera Province. Forum Pascasarjana 35(1) : 1-13.

Siregar, T.H. \& Suhendry, I. (2013). Budidaya dan Teknologi Karet. Penebar Swadaya. Jakarta.

Sdoodee, S. \& S. Rongsawat. (2012). Impact of climate change on smallholders' rubber production in Songkhla province, southern Thailand. Proceedings International and National Conference for the Sustainable Community Development of Local Community: The Foundation of Development in the ASEAN Economic Community (AEC)" February. 
Soepadmo, B., (1990). Selection of recommended clones by ecosystem approaches. In Lokakarya Nasional Pemuliaan Tanaman Karet 1990, Pontianak (Indonesia), 14-17 Jul 1990. Puslitbun.

Supriadi, H. (2012). Peran tanaman karet dalam mitigasi perubahan iklim. Jurnal Tanaman Industri dan Penyegar3(1): 79-90.

Purbaya, M., Sari, T.I., Saputri, C.A. \& Fajriaty, M.T. (2011). Pengaruh Beberapa Jenis Bahan Penggumpal Lateks dan Hubungannya Dengan Susut Bobot, Kadar Karet Kering dan Plastisitas.

Umar, H., et al. (2010). Production analysis of budded rubber stumps in Rubber Research Institute of Nigeria (RRIN). Journal of Agricultural Science1(10).

Vijayakumar, K.R., Thomas, K.U. and Rajagopal, R. (2000). Tapping. Natural rubber, agro management and crop processing. Rubber Research Institute of India, Kottayam, pp.215-238.

Wijaya, T., (2013). The effect of rain guard on reducing latex loss. Journal of Materials Science and Engineering. A, 3(8A), p.564.

Wiguna, H. (2017). Manajemen Penyadapan Karet (Hevea brasiliensis Muell Arg.) Perkebunan Karet di Simalungun, Sumatera, Utara. Buletin Agrohorti3(2): 232-244.

Woelan, S., Sayurandi, S. \& Irwansyah, E. (2014). Ketagaman Genetika Tanaman Karet (Hevea brasiliesnsis Muell. Arg) dari Hasil Persilangan Interspesifik. Jurnal Penelitian Karet, 32(2), pp.109-121.

Yeang, H. Y. (2007). Synchronous flowering of the rubber tree (Hevea brasiliensis) induced by high solar radiation intensity. New Phytologist175(2): 283-289.

Zomer, R. J., et. al. (2014). Environmental stratification to model climate change impacts on biodiversity and rubber production in Xishuangbanna, Yunnan, China. Biological Conservation170: 264-273. 